\title{
Studies of the In Vivo Behavior of Human C'3 in Normal Subjects and Patients*
}

\author{
Chester A. Alper and Fred S. Rosen $\$$ with the technical assistance of \\ LiLlian Watson \\ (From the Departments of Medicine, Children's Hospital Medical Center and Peter Bent \\ Brigham Hospital, the Departments of Medicine and Pediatrics, Harvard Medical \\ School, and the Blood Grouping Laboratory, Boston, Massachusetts)
}

Summary. The metabolic behavior of C'3 labeled with radioactive iodine was investigated in 10 normal subjects and in 20 patients with diseases in which complement is thought to play a pathophysiological role. The mean fractional catabolic rate of $\mathrm{C}^{\prime} 3$ in normal subjects was $2.3 \pm 1.0 \%$ of the plasma pool per $\mathrm{hr}$, whereas the fractional catabolic rate of $\mathrm{C}^{\prime} 3_{\mathrm{i}}$, the inactive conversion product of $\mathrm{C}^{\prime} 3$ produced by complement activation, was at least five times as great.

Increased catabolic rates were found in some patients with acute glomerulonephritis, systemic lupus erythematosus, idiopathic nephrotic syndrome of childhood, and progressive glomerulonephritis. Depressed synthesis was found in each of four studies of patients with progressive glomerulonephritis and seemed to be the major factor in the lowering of plasma $\mathrm{C}^{\prime} 3$ concentrations regularly observed in patients with this disease. Of three patients with acute glomerulonephritis, synthesis rates of $\mathrm{C}^{\prime} 3$ were markedly depressed in one subject, at the lower limit of normal in another, and entirely normal in the third. Increased extravascular: plasma pool ratios were observed in the studies of $C^{\prime} 3_{i}$ metabolism in a normal subject, and of $C^{\prime} 3$ metabolism in two of three patients with acute glomerulonephritis, in one of four patients with systemic lupus erythematosus, and in one patient with idiopathic nephrotic syndrome. The increased pool ratios are possibly compatible with tissue attachment of part of the injected $\mathrm{C}^{\prime} 3$ or its conversion products.

No important abnormalities of metabolism were found in patients with acquired hemolytic anemia, paroxysmal nocturnal hemoglobinuria, hereditary angioneurotic edema, or rheumatoid arthritis.

By means of antigen-antibody crossed electrophoresis, $\mathbf{C}^{\prime} \mathbf{3}_{1}$ could be demonstrated in the fresh plasma of three of eight patients who had acute glomerulonephritis. This finding was used as evidence for in vivo complement activation in this disease. Since $\mathbf{C}^{\prime} \boldsymbol{3}_{\mathrm{i}}$ was demonstrated only in plasma from patients with very low plasma concentrations whose onset of symptoms was very recent, there may be two phases in the metabolism of $\mathrm{C}^{\prime} 3$ : early complement activation with resultant increased catabolism and later depressed synthesis, both of which lead to lowered serum concentrations.

\footnotetext{
* Received for publication 8 June 1965 and in revised form 3 August 1967.

Supported by grants from the U. S. Public Health Service (AM 05877, AM 00965, FR 00128, 8 MO 1-FR31-05, and NB 03492) and The John A. Hartford Foundation. Reported partially at a sectional meeting of
}

The American Society for Clinical Investigation, 2 May 1965.

$\ddagger$ Recipient of a career development award (1-K3-AM-

$19,650)$ from the U. S. Public Health Service.

Address requests for reprints to Dr. Chester A. Alper, The Blood Grouping Laboratory, 332 Longwood Avenue, Boston, Mass. 02115. 


\section{Introduction}

Progress in our understanding of complement activation in vitro has been greatly facilitated in recent years by the isolation of several complement components in relatively pure form $(1,2)$. These achievements have also made possible, for the first time, the study of the metabolism of these components in normal subjects and in patients with diseases in which serum total hemolytic complement concentration is lowered, or in which complement is thought to be involved in a pathophysiological way.

In the present report we are concerned with the metabolic behavior of $\mathrm{C}^{\prime} 3$, or its conversion products, in normal subjects and in patients with acute glomerulonephritis, progressive glomerulonephritis, systemic lupus erythematosus, and several other conditions. It is known that $C^{\prime} 3$ concentration in serum is regularly low in patients with acute and progressive glomerulonephritis and is often low in patients with systemic lupus erythematosus (3-7).

We have investigated the mechanisms that lower the serum $\mathrm{C}^{\prime} 3$ concentration in these patients by examining the fate of intravenously administered, radioactive iodine-labeled $C^{\prime} 3$. In addition, the fresh plasma from a group of such patients has been examined for evidence of circulating, inactive conversion products by the sensitive antigen-antibody crossed electrophoresis technique of Laurell (8).

Some of our early studies of the behavior of ${ }^{131} \mathrm{I}-$ labeled $C^{\prime} 3$ in normal subjects and in patients with progressive and acute glomerulonephritis have been reported briefly elsewhere (9).

\section{Methods}

Patients. A summary of some pertinent clinical data of the patients studied with $\mathrm{C}^{\prime} 3$ labeled with radioactive iodine is given in Table $\mathrm{I}$. Each patient received five drops of a saturated solution of potassium iodide by mouth three times daily, immediately before and throughout the metabolic studies in order to block uptake of labeled iodine by the thyroid.

Normal subjects. 10 physicians (age, from 26 to 36 $\mathrm{yr}$ ), including 9 males and 1 female, served as normal subjects. All were in apparently excellent health. They also received potassium iodide during the metabolic studies.

Preparation and labeling of $C^{\prime} 3$. For the earlier studies, $C^{\prime} 3$ was prepared from the serum of hepatitis-free blood donors by the original method of Müller-Eberhard,
Nilsson, and Aronsson (10) ( $\left.C^{\prime} 3 \mathrm{I}\right)$. When the improved method of Nilsson and Müller-Eberhard became available (11), $C^{\prime} 3$ was prepared for the later studies by the newer technique (C'3 II). These methods were applied without modification, with the exception of the newer method in which fractions from hydroxylapatite chromatography containing only $\mathrm{C}^{\prime} 3$, as judged by Ouchterlony analysis with antisera to whole human serum and to partially purified $C^{\prime} 3$, were not concentrated by euglobulin precipitation. Instead, these pooled fractions were dialyzed overnight at $4^{\circ} \mathrm{C}$ against two changes of $20-40$ volumes of starting buffer for TEAE cellulose chromatography. The fractions were then passed over two small columns containing about $6 \mathrm{ml}$ of packed TEAE cellulose equilibrated with starting buffer and connected in tandem. The columns were disconnected after the material had completely washed through and the $\mathrm{C}^{\prime} 3$ from each was eluted in a small volume with $0.15 \mathrm{M}$ phosphate buffer at pH 6.0.

Purified $\mathrm{C}^{\prime} 3$ was labeled either with ${ }^{131} \mathrm{I}$ or ${ }^{125} \mathrm{I}$ by the iodine monochloride technique of McFarlane (12) or with a modification of this method (13). Radioactive iodine, not bound to protein, was removed by exhaustive dialysis in the cold against $0.03 \mathrm{M}$ phosphate buffer at $\mathrm{pH}$ 8.1. After dialysis at least $97 \%$ of the label was precipitated by $10 \%$ trichloroacetic acid. We added sterile human serum albumin to solutions of labeled $C^{\prime} 3$ to reduce self-irradiation of the protein and the solutions were passed through Millipore filters for sterilization.

Purity and homogeneity of labeled $C^{\prime} 3$. Labeled $C^{\prime} 3$ I was about $82 \%$ pure, as judged by precipitation of labeled protein by a monospecific antiserum in antibody excess. Paper electrophoresis (14) and radioautography revealed the label to be in the form of a band with the mobility of $C^{\prime} 3$ with some label trailing from the origin. On immunoelectrophoresis (15) and radioautography, two low concentration contaminants could be detected with an antiserum to partially purified $C^{\prime} 3$. These probably were beta $_{1 \mathrm{~B}}$ globulin and $\mathrm{C}^{\prime} 5$ (11). Using the latter techniques, we found that after incubation with hydrazine $(16,17)$ or $\mathrm{EAC}^{\prime}{ }_{1,4,2}(16)$ the major radioactive arc was transformed into an arc with the mobility of $C^{\prime} 3_{1}$ (2).

Labeled C'3 II was studied in starch gel (18) and agarose (19) electrophoreses and by radioautography of the stained runs. These patterns are shown in Figs. 1 and 2. As can be seen, the radioactivity was essentially in the $C^{\prime} 3$ band. When labeled $C^{\prime} 3$ was added to sterile normal human serum and the mixture allowed to stand at room temperature $\left(25-26^{\circ} \mathrm{C}\right)$ for 5 days, both the agarose electrophoretic pattern and the radioautograph of this pattern showed $\mathrm{a}$ band in the rapid beta region, corresponding to the mobility of $C^{\prime} 3_{1}$; however, the original $C^{\prime} 3$ band had completely disappeared.

Both preparations after labeling and Millipore filtration were as effective in restoring the total serum hemolytic complement activity of a patient with progressive glomerulonephritis as the unlabeled, unfiltered material (4, 20). This finding confirms the observation that labeling with radioactive iodine does not alter the complement activity of $C^{\prime} 3$ (21). 
TABLE I

Clinical dala

\begin{tabular}{|c|c|c|c|c|c|c|c|}
\hline Subject & Diagnosis* & Sex & Age & $\underset{\text { sym }}{\text { Dura }}$ & $\begin{array}{l}\text { ation of } \\
\text { nptoms }\end{array}$ & Therapy & Comments \\
\hline C.B.C. & SLE & $\mathbf{F}$ & 16 & 3 & months & ASA & Het $20 \%$. Retics $1.2 \%$, Coombs -. LE cells present \\
\hline M.J.P. & SLE & $\mathbf{F}$ & 15 & 2 & yr ${ }^{*}$ & pred. & Het $38 \%$, Retics $12.7 \%$, Coombs + , LE cells present \\
\hline D.L. & SLE & $\mathbf{F}$ & 14 & 1.5 & months & None & Latex fixation positive, LE cells present \\
\hline S.F. & SLE & $\mathbf{F}$ & 8 & 1.5 & “ & “ & Het $24 \%$, Retics $1 \%$, Coombs -, LE cells present \\
\hline J.F. & AGN & $\mathbf{F}$ & 11 & 4 & days & pen. & BUN $53 \mathrm{mg} / 100 \mathrm{ml}$, proteinuria $2.2 \mathrm{~g} / 24 \mathrm{hr}$ \\
\hline S.T. & AGN & $\mathbf{M}$ & 9 & 2 & “ & “ & BUN $50 \mathrm{mg} / 100 \mathrm{ml}$, proteinuria $0.61 \mathrm{~g} / 24 \mathrm{hr}$ \\
\hline B.B. & AGN & $\mathbf{M}$ & 6 & 3 & “ & “ & BUN $21.5 \mathrm{mg} / 100 \mathrm{ml}$, proteinuria $0.1 \mathrm{~g} / 24 \mathrm{hr}$ \\
\hline V.O. & PGN & $\mathbf{F}$ & 13 & 2 & yr & None & BUN $25 \mathrm{mg} / 100 \mathrm{ml}$, proteinuria $5.6 \mathrm{~g} / 24 \mathrm{hr}$ \\
\hline J.L. & PGN & $\cdot \mathbf{F}$ & 12 & 4 & “ & “ & BUN $13 \mathrm{mg} / 100 \mathrm{ml}$, proteinuria $2.1 \mathrm{~g} / 24 \mathrm{hr}$ \\
\hline J.G. & PGN & $\mathbf{M}$ & 14 & 2 & “ & pred. & Serum creat. $1 \mathrm{mg} / 100 \mathrm{ml}$, proteinuria $4 \mathrm{~g} / 24 \mathrm{hr}$ \\
\hline K.O. & NS & $\mathbf{M}$ & 9 & 5 & “ & “ & $\begin{array}{l}\text { Serum creat. } 0.55 \mathrm{mg} / 100 \mathrm{ml} \text {, proteinuria } 0.9 \mathrm{~g} / 24 \mathrm{hr} \text {, } \\
\text { chol. } 248 \mathrm{mg} / 100 \mathrm{ml}\end{array}$ \\
\hline M.J.K. & NS & $\mathrm{F}$ & 9 & 4 & “ & “ & $\begin{array}{l}\text { Serum creat. } 0.52 \mathrm{mg} / 100 \mathrm{ml} \text {, proteinuria } 4.4 \mathrm{~g} / 24 \mathrm{hr} \text {, } \\
\text { chol. } 253 \mathrm{mg} / 100 \mathrm{ml}\end{array}$ \\
\hline P.A. & AHA & $\mathbf{M}$ & 69 & 2 & months & pred. chloramb. & Chronic lymphocytic leukemia, Coombs + , WBC 300,000 \\
\hline H.L. & AHA & $\mathbf{M}$ & 75 & 20 & yr & None & Cold agglutinin titer $1: 10,240$, cryoglobulin + \\
\hline M.S. & PNH & $\mathrm{F}$ & 28 & 6 & “ & FeSO4 & Het $35 \%$, Retics $8 \%$, Ham test + \\
\hline S.P. & PNH & $\mathbf{M}$ & 45 & 6 & “ & None & Het $26 \%$, Retics $14 \%$, Ham test + \\
\hline A.T. & HANE & $\mathbf{M}$ & 40 & 32 & “ & “ & Symptomatic during study, EI $0 \mathrm{U} / \mathrm{ml}$ \\
\hline H.A.S. & HANE & $\mathbf{M}$ & 48 & 41 & “ & “ & Asymptomatic during study, EI $0 \mathrm{U} / \mathrm{ml}$ \\
\hline M.R. & $\mathbf{R A}$ & $\mathbf{F}$ & 12 & 5 & “ & ASA & Latex fixation test positive \\
\hline D.S. & SGN & $\mathbf{F}$ & 11 & 1 & month & None & $\begin{array}{l}\text { Serum creat. } 1.28 \mathrm{mg} / 100 \mathrm{ml} \text {, proteinuria } 3.5 \mathrm{~g} / 24 \mathrm{hr} \text {. } \\
\text { glomerular crescent formation and adhesions }\end{array}$ \\
\hline
\end{tabular}

* SLE, systemic lupus erythematosus; AGN, acute glomerulonephritis; PGN, progressive glomerulonephritis; NS, idiopathic nephrotic syndrome; AHA, acquired hemolytic anemia; PNH, paroxysmal nocturnal hemoglobinuria; HANE, hereditary angioneurotic edema; RA, rheumatoid arthritis; SGN, subacute glomerulonephritis.

$\ddagger$ ASA, acetylsalicylic acid; pred., prednisone; pen., penicillin; chloramb., chlorambucil.

Preparation of labeled $C^{\prime} 3_{\imath}$. On two separate occasions, ${ }^{131}$ I-labeled $C^{\prime} 3$ was converted to labeled $C^{\prime} 3_{1}$ for metabolic studies of normal subject R.W. To sterile serum from this subject, we added ${ }^{121}$ I-labeled $\mathrm{C}^{\prime} 3$ in veronal buffer with calcium and magnesium (22). A thricewashed specific precipitate of rabbit anti-bovine serum albumin and bovine serum albumin was added and the mixture was incubated at $37^{\circ} \mathrm{C}$ for $30 \mathrm{~min}$. The precipi. tate was then removed by centrifugation and the supernatant sterilized by Millipore filtration. Approximately $5 \%$ of the radioactivity remained on the specific precipitate after washing with ice-cold phosphate buffered physiological saline at $\mathrm{pH}$ 7.4. When the supernatant was examined by agarose electrophoresis and radioautography, $90 \%$ or more radioactivity was in the form of $\mathrm{C}^{\prime} 3_{\mathrm{i}}$.

Administration of labeled proteins. Each subject received $2-10 \mu \mathrm{c}$ of either ${ }^{181} \mathrm{I}$ - or ${ }^{125} \mathrm{I}$-labeled $\mathrm{C}^{\prime} 3$ intrave- nously. Normal subject R.W. received ${ }^{131}$ I-labeled $C^{\prime} 3_{1}$ on one occasion, and ${ }^{131}$ I-labeled $C^{\prime} 3_{1}$ and ${ }^{125}$ I-labeled $C^{\prime} 3$ as a double study on another occasion. No subject exhibited any untoward reaction.

Collection and analysis of samples. All samples were analyzed for radioactivity with either a Baird-Atomic or a Packard gamma scintillation counter. Where two isotopes were administered simultaneously, appropriate discrimination techniques were employed. We found the number of counts administered to each subject by counting a small aliquot of the dose (of known volume or weight, or both) and by determining the volume or weight, or both, of the material injected.

Blood was collected, with EDTA as anticoagulant, at frequent intervals after administration of labeled protein, beginning at $10 \mathrm{~min}$ and continuing for 5-7 days. Red blood cells were separated from plasma by centrifugation.

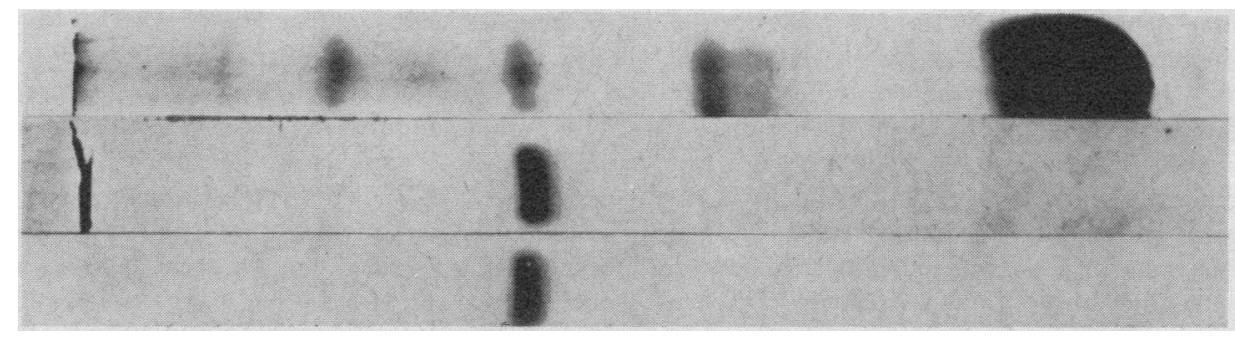

Fig. 1. Starch gel electrophoretic patterns of WhOle human SERUM (TOP) AND PURIFIED, RADIOIODINATED C'3 II (MIDDLE) STAINED WITH AMIDO BLACK. The bottom pattern is the radioautograph of the middle pattern. The anode is to the right and the origin is visible in the top two patterns at the left. 


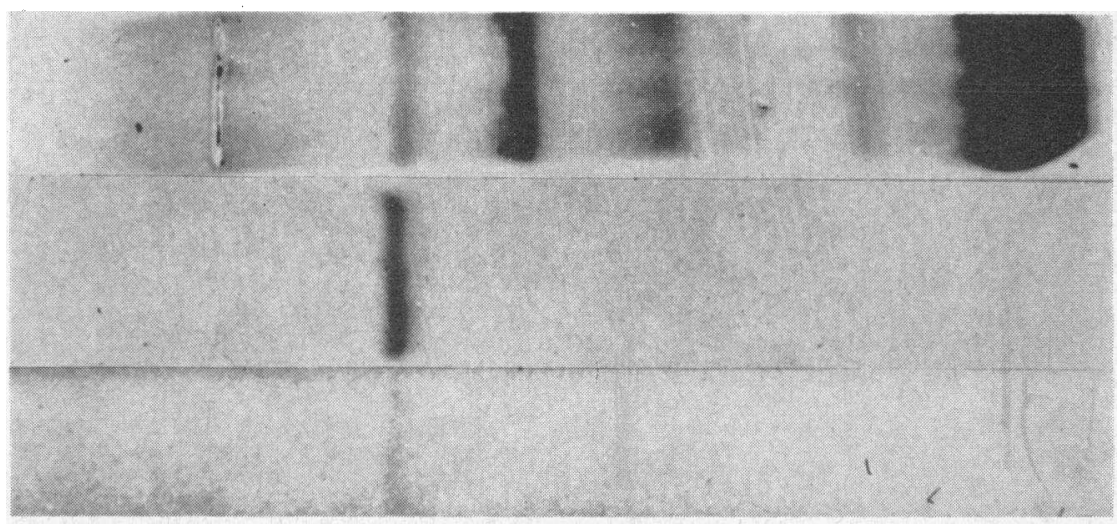

Fig. 2. Agarose electrophoretic patterns of Whole serum and pUrified, RadioIODINATED C'3 II AND THE RADIOAUTOGRAPH OF THE LATTER, AS IN Fig. 1.

In patients with hemolytic anemia, the red cells were washed three times in cold phosphate buffered physiological saline and counted. In all patients, $2.0,3.0$, or $4.0 \mathrm{ml}$ of plasma from each blood sample was counted. In addition, protein-bound radioactivity was determined in each plasma sample by precipitating the plasma proteins with $10 \%$ trichloroacetic acid, washing the precipitate twice in $10 \%$ trichloroacetic acid, and recounting the samples after removal of the supernatant by centrifugation.

All urine voided during the metabolic studies was collected in suitable portions, the volume of each portion was measured, and from 4.0 to $10.0 \mathrm{ml}$ removed for counting. We determined protein-bound radioactivity in all the urine samples from patients with significant proteinuria by adding human serum albumin, precipitating and counting as outlined for the plasma samples.

Stool was also collected throughout the studies of J.L., H.L., and the first study of V.O. Samples were counted in a large well that accommodated the entire specimens in polyethylene bags.

Total body counting. Total counts for normal subjects F.R. and C.A. and patients J.G. and V.O. (in the second study of V.O.) were made with a total body counter, as well as by the usual methods.

Concentration of $C^{\prime} 3$ in plasma. Portions of EDTA plasma from samples drawn at the beginning, in the middle, and at the end of each turnover study were stored at $-70^{\circ} \mathrm{C}$ for later determination of the $\mathrm{C}^{\prime} 3$ concentration. The immunochemical method of Feinberg (23) was used for all samples. In some instances, we used a different immunochemical technique (24) to check the results. In general, the results by the two methods agreed within $10 \%$. To convert results to $\mathrm{mg} / 100 \mathrm{ml}$ of $\mathrm{C}^{\prime} 3$, two experiments were performed. ${ }^{131} \mathrm{I}$-labeled $\mathrm{C}^{\prime} 3 \mathrm{I}$ was prepared from the serum of a normal individual, added to a second lot of the same serum, and reisolated. The protein content of the final preparation was determined by optical density at $280 \mathrm{~m} \mu$ with Yachnin's estimate of the extinction coefficient for $\mathrm{C}^{\prime} 3$ (25). From the number of counts per minute introduced into the second serum lot, the volume of this lot, and the specific activity of the final preparation, we calculated that this serum contained $150 \mathrm{mg} / 100 \mathrm{ml}$ of $\mathrm{C}^{\prime} 3$. In the second experiment, $\mathrm{C}^{\prime} 3 \mathrm{II}$ in saline was used in serial dilution in Laurell's electroimmunochemical technique (24). The distance of migration from well to tip was found to be directly proportional to relative concentration after $6 \mathrm{hr}$ of electrophoresis. However, when a standard plasma sample was examined in serial dilution in the same manner, the curve was bowed somewhat upward. Therefore, plasma standards at various dilutions were employed in all determinations of plasma samples in this study. The absolute protein content of the $C^{\prime} 3$ II solution in these experiments was determined by the Folin-Ciocalteu method (26) with purified IgG as a standard, and nitrogen content was determined by the Kjeldahl method (27). A comparison of these methods indicated that the mean $\mathrm{C}^{\prime} 3$ concentration in 28 normal individuals was about $180 \mathrm{mg} / 100 \mathrm{ml}$. To show consistency with our earlier results, we have related all concentrations to our original figure. The comparison between the metabolic behavior of $C^{\prime} 3$ in normal subjects and patients is not affected regardless of the absolute concentration used as the normal mean.

Calculation of metabolism. The Matthews' method (28) of analysis was used to calculate: $(a)$ catabolic rates as per cent of the plasma pool of $\mathrm{C}^{\prime} 3$ per hour ; $(b)$ synthesis rates as $\mathrm{mg}$ of $\mathrm{C}^{\prime} 3$ per kilogram per hour; and $(c)$ extravascular: plasma pool ratios. This method of analysis assumes, among other things, that catabolism occurs in a pool in rapid equilibrium with the plasma, and that a steady state holds with respect to the protein studied. The first assumption was tested in normal subjects and patients whose total body radioactivity curve was clearly parallel to the protein-bound plasma radioactivity curve in the latter part of the study by plotting urinary excretion of label divided by the mean plasma radioactivity during that period vs. time (29). Such plots were, in general, horizontal from about 5 to $10 \mathrm{hr}$. One such plot, derived from direct total body counts from the data in the study of patient J. G., is shown in Fig. 3. The data from this same group of patients were also analyzed by Nosslin's original method described in reference 30 and, 

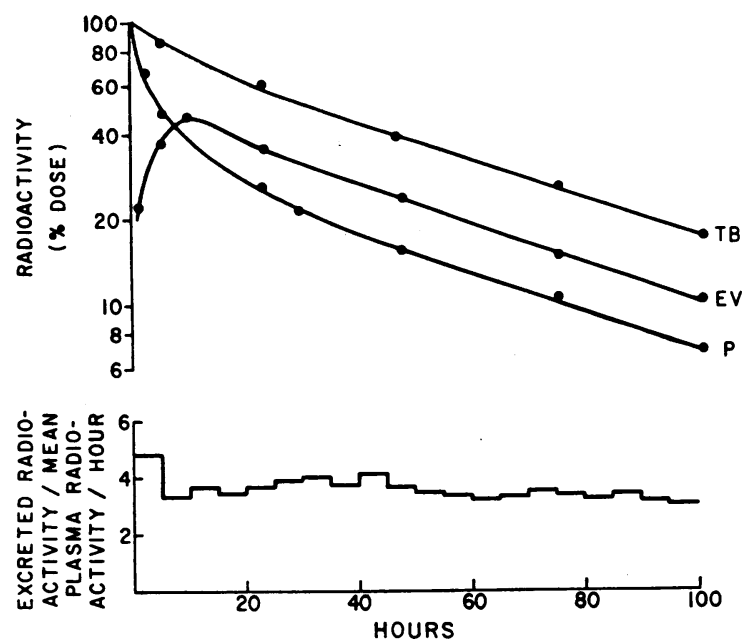

Fig. 3. The top PORTION OF THE Figure SHOWS THE PLOTS OF TOTAL BODY RADIOACTIVITY (TB), PLASMA RADIOACTIVITY (P), AND EXTRAVASCULAR RADIOACTIVITY (EV) AS PER CENT OF DOSE IN THE STUDY OF PATIENT J.G. The total body radioactivity was determined in a total body counter. Extravascular radioactivity was calculated from the relationship $E V=T B-P$. The bottom portion of the figure shows the plot on a linear scale of the ratio of excreted radioactivity per $5 \mathrm{hr}$ period to the mean plasma protein-bound radioactivity during that period.

assuming that the iodine excretion constant was between 1 and 3 , no evidence for catabolism occurring in an extravascular pool could be found. Since each plasma sample from any one subject had a $\mathrm{C}^{\prime} 3$ concentration within $10 \%$ of the mean of three samples taken at various times during the study of that subject, the assumption of the steady state seemed justified.

Since it is possible that some of the labeled $\mathrm{C}^{\prime} 3$ was cleared from the plasma during the $10 \mathrm{~min}$ mixing period before the drawing of the first blood sample, we used ${ }^{125} \mathrm{I}$ labeled albumin (Albumotope, E. R. Squibb \& Sons, New York) to determine plasma volume at the conclusion of the turnover studies in several subjects. Should significant loss during mixing have occurred, the plasma volume, as determined from the volume of distribution of labeled $\mathrm{C}^{\prime} 3$, would have been significantly higher than the one obtained from the volume of distribution of labeled albumin. Similarly, from the double study of normal subject R. W. a comparison of the plasma volumes obtained from the distribution volumes of labeled $C^{\prime} 3$ and labeled $C^{\prime} 3_{1}$ would give information on the clearance of $\mathrm{C}^{\prime} 3_{1}$ during the mixing phase. Where plasma volumes determined by labeled $C^{\prime} 3$ were higher than those obtained by labeled albumin, or when volumes obtained by labeled $C^{\prime} 3_{1}$ differed from the volumes obtained by labeled $\mathrm{C}^{\prime} 3$ (in the double study), a correction could be applied to the first plasma sample. Knowing the "true" plasma volume and the overestimated plasma volume, the "true" $10 \mathrm{~min}$ plasma radioactivity must therefore equal the observed radioactivity in the initial sample. times the ratio between overestimated and "true" plasma volumes. All plasma radioactivities could then be expressed as per cent of this corrected $10 \mathrm{~min}$ sample radioactivity.

The detection of circulating conversion products of $C^{\prime} 3$. The antigen-antibody crossed electrophoresis technique of Laurell (8) was used as a sensitive means for detecting $C^{\prime} 3$ conversion products in fresh EDTA plasma of 16 normal subjects and 20 patients with a variety of disorders, as well as in fresh plasma promptly frozen at $-70^{\circ} \mathrm{C}$. Since this technique became available after part of our study had been completed, not all turnover patients were examined in this way. However, additional patients were studied by this technique who were not studied metabolically. Sera studied by antigen-antibody crossed electrophoresis were also examined by immunoelectrophoresis (15) with potent anti-C'3 antiserum.

For comparison with the patterns produced by $\mathrm{C}^{\prime} 3$ in the normal subjects and patients, the conversion of $\mathrm{C}^{\prime} 3$ in fresh serum by antigen-antibody specific precipitates was examined as described by Laurell and Lundh (31). Conditions for conversion are outlined in the preceding section on the preparation of labeled $C^{\prime} 3_{1}$. The extent of conversion was estimated by making a photographic enlargement of the antigen-antibody crossed electrophoresis pattern, cutting out the $C^{\prime} 3$ and $C^{\prime} 3_{1}$ peaks, and weighing them. The weight of each peak was expressed as the per cent of the total weight.

\section{Results}

The plasma radioactivity curves of labeled $\mathrm{C}^{\prime} 3$ in 10 normal subjects are shown in Fig. 4. The calculated parameters of metabolism of this protein in our studies are listed in Table II. Values for all parameters fall within rather narrow ranges, especially when these values are compared with those observed in some patients.

Fig. 4 also illustrates the metabolic behavior of

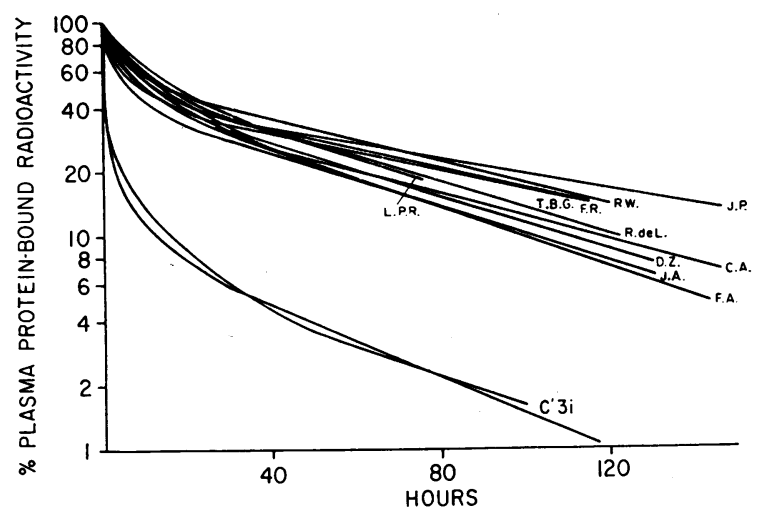

Fig. 4. The plasma radioactivity curves of $\mathrm{C}^{\prime} 3$ LABELED WITH RADIOACTIVE IODINE IN 10 NORMAL SUBJECTS (INITIALS) AND THE PLASMA RADIOACTIVITY CURVES OF LABELED C'3, IN NORMAL SUBJECT R.W. 
TABLE II

Melabolism of $C^{\prime} 3$ in normal subjects

\begin{tabular}{|c|c|c|c|c|c|}
\hline Subject & $C^{\prime} 3$ preparation* & $C^{\prime} 3$ concentration & Catabolic rate & Synthesis rate & $\begin{array}{l}\text { Extravascular } \\
\text { pool/plasma ratio }\end{array}$ \\
\hline & & $m g / 100 \mathrm{ml}$ & $\%$ plasma pool/hr & $m g / k g$ per $h r$ & \\
\hline T.B.G. & I & 150 & 2.03 & 1.2 & 1.14 \\
\hline R.deL. & I & 162 & 2.34 & 1.5 & 0.57 \\
\hline D.Z. & $\bar{I}$ & 165 & 2.81 & 1.7 & 0.83 \\
\hline F.A. & I & 150 & 3.01 & 1.9 & 0.75 \\
\hline L.P.R. & I & 150 & 2.55 & 1.3 & 0.67 \\
\hline J.P. & I & 150 & 1.69 & 1.1 & 0.82 \\
\hline C.A. & II & 127 & 2.24 & 1.3 & 1.25 \\
\hline F.R. & II & 150 & 2.11 & 1.4 & 0.94 \\
\hline J.A. & II & 110 & 3.11 & 1.3 & 0.94 \\
\hline R.W. & II & 170 & 1.58 & 1.1 & 1.04 \\
\hline R.W. & $C^{\prime} 3_{i}$ II & 170 & $15.98 \ddagger$ & & $3.07 \ddagger$ \\
\hline R.W. & $\mathrm{C}^{\prime} 3_{\mathrm{i}} \mathrm{II}$ & 162 & $16.52 \ddagger$ & & $5.03 \ddagger$ \\
\hline \multicolumn{2}{|c|}{ Mean of normals $\pm 2 \mathrm{sD} \S$} & $148.4 \pm 35.7$ & $2.35 . \pm 1.05$ & $1.38 \pm 0.51$ & $0.90 \pm 0.41$ \\
\hline
\end{tabular}

* See text for explanation of $\mathrm{C}^{\prime} 3 \mathrm{I}, \mathrm{C}^{\prime} 3 \mathrm{II}$, and $\mathrm{C}^{\prime} 3_{\mathbf{i}} \mathrm{II}$.

$\ddagger$ These calculations are based on corrected plasma volumes (see text and Table V).

$\$$ Refers to $C^{\prime} 3$ only.

labeled $C^{\prime} 3_{i}$ in two studies for normal subject R.W. It is clear that the metabolic fate of this material is strikingly different from that of $\mathrm{C}^{\prime} 3$ because of its clearance rate from the plasma. The rapid appearance of nonprotein-bound iodide in the urine in these two studies corroborated the assumption that the rapid clearance from the plasma represented rapid catabolism. The metabolic parameters of $C^{\prime} 3_{i}$ in these studies are also given in Table II. It can be seen that not only is the fractional catabolic rate of $\mathrm{C}^{\prime} 3_{\mathrm{i}}$ from 5 to 10 times greater than that of $\mathrm{C}^{\prime} 3$ in normal subjects, but that the extravascular: plasma pool ratio is greater than that of $\mathrm{C}^{\prime} 3$.

Fig. 3 shows both the plasma protein-bound radioactivity curve and the total body radioactivity curve of patient J.G. with progressive glomerulonephritis. The fractional catabolic rate was found to be $5.2 \%$ of the plasma pool per hr by Matthews' analysis and the mean excreted radioactivity divided by the mean plasma protein-bound radioactivity was $3.6 \%$ of the plasma pool per hr. These rates represent a mild-to-moderate increase over the normal rate (Table II). Patient V.O. with progressive glomerulonephritis was studied twice in a $1 \mathrm{yr}$ period. Her $\mathrm{C}^{\prime} 3$ concentration and general clinical condition remained unchanged. It is evident from the calculated data presented in Table III that there was no important difference in metabolic behavior with either of the two labeled preparations. In a similar manner, the identical behavior of the two preparations in normal subjects (Table II) supports the impression that both preparations are metabolically indistinguishable. As reported earlier (9), and herein amplified, reduced synthesis rates of $C^{\prime} 3$ in patients with progressive glomerulonephritis may be the major factor in the lowering of serum $\mathrm{C}^{\prime} 3$ concentrations regularly observed in these patients. Depressed synthesis was observed in all four of our studies of patients with this disease (Table III). Fractional catabolic rates in these patients were either normal, or at most only moderately elevated, despite extremely low concentrations. Total body curves were parallel to plasma protein-bound radioactivity curves, and pool ratios in the studies of these patients, including those subjects with total body counts, did not differ from those ratios in normal subjects. It therefore seems very unlikely that significant clearance of label had occurred before the drawing of the first $(10 \mathrm{~min})$ blood sample. This point is further substantiated by the fact that plasma volumes calculated from the number of counts per minute in the first plasma sample, and the number of counts administered, are in the expected range for these patients. Protein-bound radioactivity in the urine accounted for less than $2 \%$ of the total radioactivity excreted during the metabolic studies in the patients with progressive glomerulonephritis. The plasma radioactivity curves for these studies (Fig. 5) are shown in comparison with the curves obtained in 
TABLE III

Metabolism of $C^{\prime} 3$ in patients

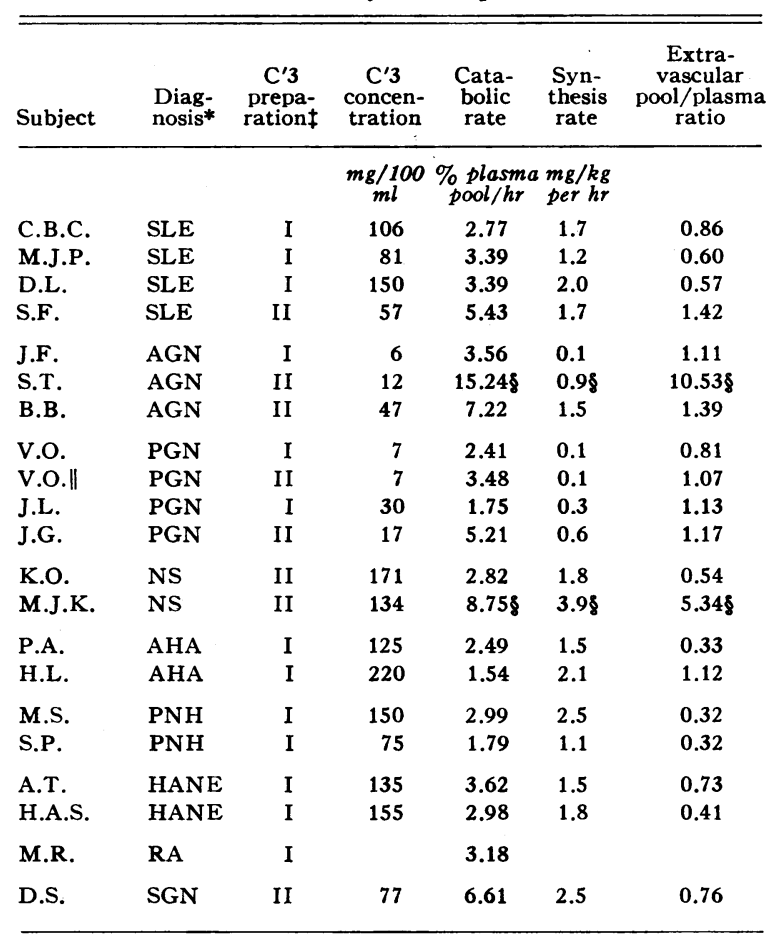

* See footnote Table I for explanation of abbreviations.

$¥$ See text for explanation of $C^{\prime} 3$ I and $C^{\prime} 3$ II.

8 These calculations are based on corrected plasma volumes (see text and Table V) where albumin plasma volumes grossly disagreed with $C^{\prime} 3$ plasma volumes. In the study of patient S.T. the $C^{\prime} 3$ plasma volume was $103 \mathrm{ml} / \mathrm{kg}$, an obvious overestimate. In the absence of an albumin determination, the plasma volume was assumed to be 50 $\mathrm{ml} / \mathbf{k g}$.

|| This study was carried out $1 \mathrm{yr}$ after the first investigation of patient V.O.

the studies of normal subjects. Excretion of label in the stool of patients V.O. and J.L. was negligible, as was excretion of label in stool for patient H.L.

The metabolic studies of three patients with acute glomerulonephritis yielded varied results, as seen both from the calculated parameters presented in Table III and the plasma radioactivity curves depicted in Fig. 6. Fractional catabolic rates in these patients varied, from slightly elevated to 5-10 times the rate in normal subjects. The rate of synthesis of $C^{\prime} 3$ was markedly depressed in one patient, at the lower limit of normal in another, and entirely normal in the third. The extravascular: plasma pool ratio was increased only in the patient with the very high catabolic rate. None of these patients showed protein-bound urinary radioactivity in excess of $3 \%$ of the amount administered.

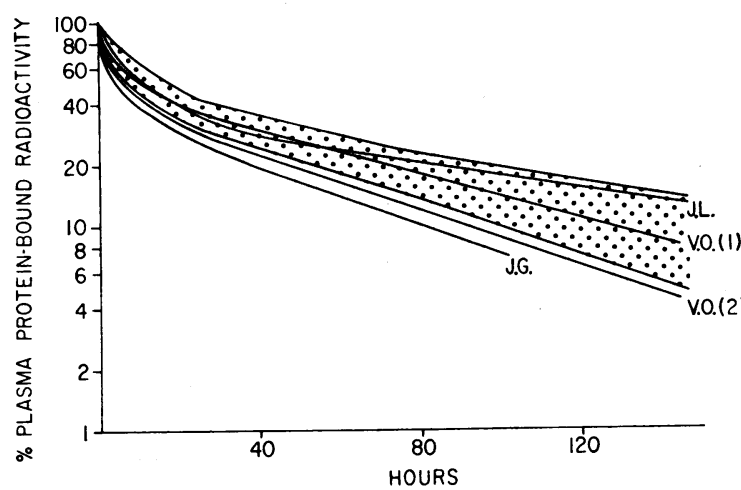

Fig. 5. The plasma radioactivity CURVes obtained IN FOUR STUDIES OF PATIENTS WITH PROGRESSIVE GLOMERULONEPHRITIS. Initials refer to patients. The two studies in patient V.O. were performed $1 \mathrm{yr}$ apart and with labeled $C^{\prime} 3$ prepared by different methods. The stippled area is the range of normal curves shown in Fig. 4.

In a single study of a patient with hematuria, nephrosis, azotemia, and a somewhat reduced plasma concentration of $\mathrm{C}^{\prime} 3$ (patient D.S.), both the fractional catabolic rate and the synthesis rate of $\mathrm{C}^{\prime} 3$ were elevated. A renal biopsy of this patient showed changes consistent with subacute glomerulonephritis.

Of the four studies of patients with systemic lupus erythematosus, only one revealed a clearly elevated fractional catabolic rate and two yielded catabolic rates at the upper limit of the normal mean $\pm 2 \mathrm{sD}$. The plasma curves of these studies are shown in Fig. 7. Synthesis rates were normal in all of these studies, as were extravascular: plasma pool ratios. No significant radioactivity could be detected on the washed erythrocytes of

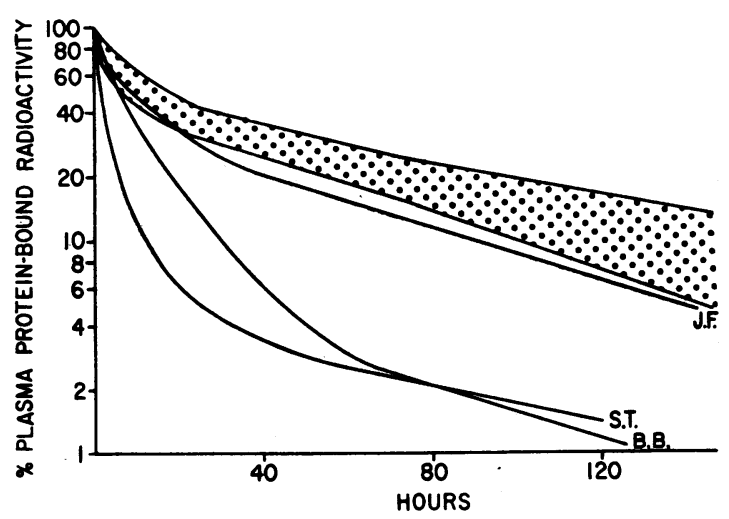

Fig. 6. The plasma Radioactivity CURVES OF THREE PATIENTS WITH ACUTE GLOMERULONEPHRITIS, AS IN Fig. 5. 


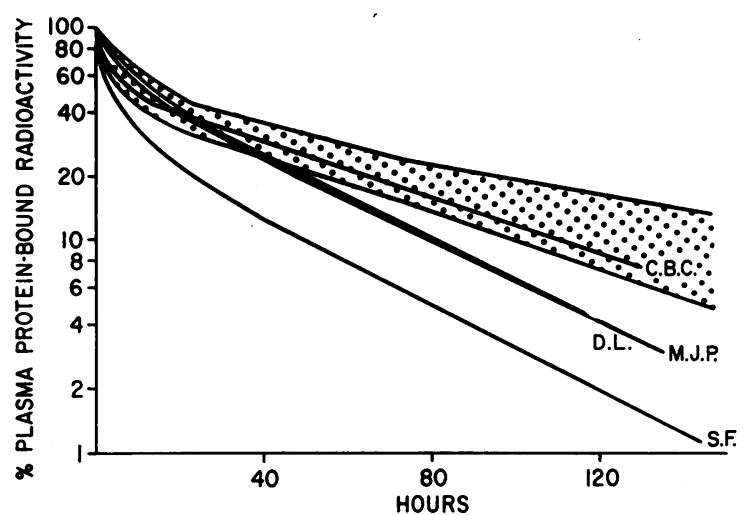

Fig. 7. The plasma Radioactivity curves of Four PATIENTS WITH SYSTEMIC LUPUS ERYTHEMATOSUS, AS IN FIG. 5.

any of these patients, nor was there more than $2 \%$ of the administered radioactivity in the form of protein-bound radioactivity in the urine.

Because it is known that catabolic and synthesis rates of several plasma proteins may be elevated in patients with idiopathic nephrotic syndrome, we studied two patients with this disorder and normal $\mathrm{C}^{\prime} 3$ serum concentrations. The patient with mild nephrosis (K.O.) exhibited normal parameters of metabolism, whereas patient M.J.K., with more severe disease, showed a fairly marked increase in fractional catabolic rate over the normal, a definite increase in the extravascular: plasma pool ratio, and a significantly increased synthesis rate of $\mathrm{C}^{\prime} 3$.

The studies in the patients with acquired hemolytic anemia, paroxysmal nocturnal hemoglobinuria, and rheumatoid arthritis revealed no definite abnormalities of metabolism. No significant radioactivity was detected on the washed red blood cells of the patients with hemolytic anemia.

Of the two patients studied with hereditary angioneurotic edema, the results of the patient who was asymptomatic during the period of study were within normal limits, whereas a slightly increased catabolic rate was found in the patient who was studied during an attack of angioedema.

A comparison of the plasma volume, calculated from the volume of distribution in plasma $10 \mathrm{~min}$ after administration of labeled $\mathrm{C}^{\prime} 3$, and that volume determined in a similar manner from the same subject with labeled human serum albumin indicated that in normal subjects, and in patients
TABLE IV

Comparison of plasma volumes determined from the volume of distribution $10 \mathrm{~min}$ after the intravenous administration of labeled protein

\begin{tabular}{lccc}
\hline \hline Subject & $\mathrm{C}^{\prime} \mathbf{3}$ & Albumin & $\mathrm{C}^{\prime} \mathbf{3}_{\mathbf{i}}$ \\
\hline & $m l$ & $m l$ & $m l$ \\
H.A.S. & 2810 & 2430 & \\
S.P. & 4800 & 4860 & \\
J.A. & 2720 & 2940 & \\
S.F. & 1640 & 1440 & \\
M.J.K. & 1665 & 930 & \\
D.S. & 1595 & 1670 & \multirow{2}{*}{3920,4660} \\
R.W. & 2735 & 3470 & \\
\hline
\end{tabular}

with normal or even mildly elevated fractional catabolic rates, the $C^{\prime} 3$ plasma volume and the albumin plasma volume were more or less in agreement (Table IV). However, the $\mathrm{C}^{\prime} 3$ plasma volume was grossly high in studies where the initial fall in plasma protein-bound radioactivity (uncorrected) was extremely rapid $\left(C^{\prime} 3_{i}\right.$ in subject R.W. on two occasions, $\mathrm{C}^{\prime} 3$ in M.J.K. and S.T.). The $\mathrm{C}^{\prime} 3_{\mathrm{i}}$ plasma volume, in similar fashion, was much greater than the $C^{\prime} 3$ plasma volume in the double study in normal subject R.W. Some catabolic and synthesis rates based on corrected plasma protein-bound radioactivities are given in Table $\mathrm{V}$ for comparison with uncorrected values. It may be concluded from these observations that in patients in whom moderately or markedly elevated rates were calculated from uncorrected plasma radioactivities, these rates may be underestimates, particularly in cases where the initial fall in plasma radioactivity is rapid. Synthesis rates are not affected by the correction, as can be seen from the data in Table V. This is to be expected, for although the catabolic rate is underestimated, the

TABLE V

The effects of correcting catabolic and synthesis rates for clearance of labeled protein during the mixing phase

\begin{tabular}{|c|c|c|c|c|c|}
\hline \multirow[b]{2}{*}{ Subject } & \multirow[b]{2}{*}{ Protein } & \multicolumn{2}{|c|}{ Uncorrected } & \multicolumn{2}{|c|}{ Corrected } \\
\hline & & $\begin{array}{l}\text { Catabolic } \\
\text { rate }\end{array}$ & $\begin{array}{l}\text { Synthesis } \\
\text { rate }\end{array}$ & $\begin{array}{l}\text { Catabolic } \\
\text { rate }\end{array}$ & $\begin{array}{c}\text { Synthesis } \\
\text { rate }\end{array}$ \\
\hline & & $\begin{array}{c}\text { \% plasma } \\
\text { pool/hr }\end{array}$ & $\begin{array}{l}\mathrm{mg} / \mathbf{k g} \\
\text { per hr}\end{array}$ & $\underset{\text { pool } / \mathrm{hr}}{\text { \% plasma }}$ & $\begin{array}{l}m g / k g \\
\text { per hr }\end{array}$ \\
\hline M.J.K. & $C^{\prime} 3$ & 5.27 & 4.2 & 8.75 & 3.9 \\
\hline R.W. & $C^{\prime} 3_{i}$ & 10.98 & $(4.96) *$ & 15.98 & $(5.04)^{*}$ \\
\hline R.W. & $C^{\prime} 3_{i}$ & 9.67 & $(5.19) *$ & 16.52 & $(5.21)^{*}$ \\
\hline
\end{tabular}

* Since there is no regularly detectable plasma pool of $C^{\prime} 3_{i}$, an arbitrary value of $100 \mathrm{mg} / 100 \mathrm{ml}$ was assigned. The relationship between the corrected and uncorrected synthesis rates is independent of absolute concentration, provided only that the same concentration is used in concentration, pro
both instances. 


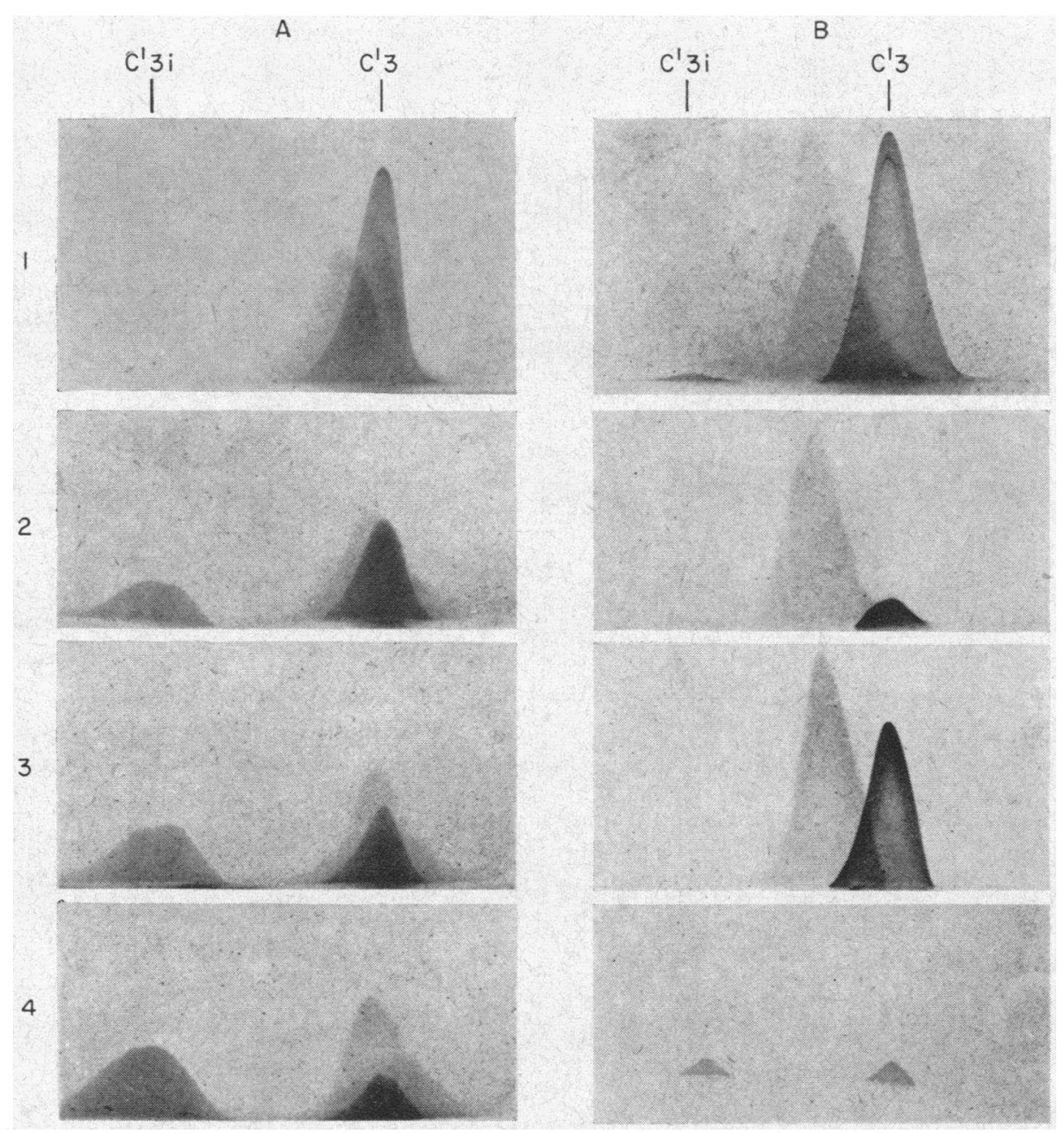

Fig. 8. ANTigen-ANtibody CROSSEd electrophoresis PATterns OF Fresh NORMal Plasma, NORMAL SERUM DURING COMPLEMENT ACTIVATION, AND FRESH EDTA PLASMA FROM SEVERAL patients. The position marked $C^{\prime} 3$ is that of the $C^{\prime} 3$ band in fresh serum or plasma seen on agarose electrophoresis and is of slow beta mobility. The $C^{\prime} 3_{1}$ position is of rapid beta mobility, and is slightly more rapid than that of transferrin. In the first electrophoresis the anode was at the left and in the second the anode was at the top. The individual patterns represent: A1, fresh normal plasma; A2, fresh normal serum incubated for $30 \mathrm{sec}$ at $32^{\circ} \mathrm{C}$ with antigen-antibody specific precipitate; $A 3$, the same after 2 min incubation; $A 4$, the same after 10 min incubation; B1, fresh normal plasma showing a small amount of material in the $\mathrm{C}^{\prime} 3_{1}$ position; B2, fresh plasma from patient VO with progressive glomerulonephritis ; B3, fresh plasma from patient SF with systemic lupus erythematosus; B4, fresh plasma from patient EW with acute glomerulonephritis. Several different lots of rabbit antiserum to human C'3 were used and except for that used in B4, antibodies to other proteins were also evident as additional peaks, all of which are lighter than the $C^{\prime} 3$ and $C^{\prime} 3_{1}$ peaks.

plasma pool is overestimated if the correction is not applied.

When the antigen-antibody crossed electrophoresis technique was applied to the fresh EDTA plasma from 16 normal individuals, small amounts of material with the mobility of $\mathrm{C}^{\prime} 3_{\mathrm{i}}$ were seen in two patterns. One such result is shown in Fig. 8. In both of these instances, the amount of material with the mobility of $\mathrm{C}^{\prime} 3_{1}$ was about $3 \%$. 3 of 8 plasma samples from patients with acute glomerulonephritis and very low concentrations of total $C^{\prime} 3$-related material showed patterns in which 
TABLE VI

The detection of conversion producls of $C^{\prime} 3$ in the plasma of patients with acute, progressive, and subacute glomerulonephritis

\begin{tabular}{|c|c|c|c|c|}
\hline Patient & $\begin{array}{l}\text { Diag- } \\
\text { nosis* }\end{array}$ & $\begin{array}{l}\text { Duration of } \\
\text { symptoms } \ddagger\end{array}$ & $\begin{array}{c}\text { C'3 } \\
\text { plasma } \\
\text { concen- } \\
\text { tration }\end{array}$ & $C^{\prime} 3_{i}$ \\
\hline & & & $\begin{array}{c}m g / \\
100 \mathrm{ml}\end{array}$ & $\begin{array}{c}\text { \%otal } \\
C^{\prime} 3\end{array}$ \\
\hline S.T. & AGN & 6 days & 12 & 0 \\
\hline B.B. & AGN & $4 \quad ،$ & 47 & 0 \\
\hline T.H. & AGN & 1 day & 18 & 16 \\
\hline M.Sm. & AGN & 2 days & 7 & 10 \\
\hline E.W. & $\mathrm{AGN}$ & $2 \quad “$ & 9 & 35 \\
\hline $\mathrm{Bu}$. & AGN & $3 \quad$ " & 35 & 0 \\
\hline I.R. & AGN & $5 \quad$ “ & 14 & 0 \\
\hline J.Gl. & $A G N$ & $2 \quad$ " & 30 & 0 \\
\hline F.M. & PGN & $2 \mathrm{yr}$ & 21 & 0 \\
\hline V.O. & PGN & 2 “ & 7 & 0 \\
\hline J.G. & PGN & 2 " & 17 & 0 \\
\hline J.L. & PGN & $1 \frac{1}{2} “$ & 30 & 0 \\
\hline D.S. & SGN & 4 wk & 77 & 0 \\
\hline
\end{tabular}

* AGN, acute glomerulonephritis; PGN, progressive glomerulonephritis; SGN, subacute glomerulonephritis.

$\ddagger$ The time blood sample was drawn for detection of conversion products.

$10-35 \%$ conversion had occurred. One of these patterns is shown in Fig. 8. Neither of the patterns of patients S.T. and B.B. with rapid catabolic rates in association with acute glomerulonephritis showed any material with the mobility of $C^{\prime} 3_{i}$. The immunoelectrophoresis of plasma of the three patients failed to show material that reacted with the antiserum against $C^{\prime} 3$ even when the antiserum was diluted. None of the immunoelectrophoreses of these patients or of patients with acute or progressive glomerulonephritis revealed reactive material with alpha ${ }_{2}$ mobility, although the antiserum produced an alpha ${ }_{2}$ arc with aged plasma. Only $\mathrm{C}^{\prime} 3$ could be detected in the plasma of the remaining patients, including those with progressive glomerulonephritis and systemic lupus erythematosus, either by antigen-antibody crossed electrophoresis or by immunoelectrophoresis. A summary of the results of these studies is presented in Table VI.

\section{Discussion}

The fractional catabolic rate of $C^{\prime} 3$ in normal subjects reported in our study is considerably greater than that for albumin and $\operatorname{IgG}(32)$. Whereas the rate for albumin is $8-12 \%$ of the plasma pool per day and that for IgG is $4-6 \%$, the rate for $\mathrm{C}^{\prime} 3$ is $30-80 \%$ of the plasma pool per day, which is similar to the rates for fibrinogen
(32) and haptoglobin (33). As is true of the latter two proteins, a mechanism superimposed on a general catabolic process that would affect all plasma proteins can be invoked to explain the relatively rapid degradation of $C^{\prime} 3$. Since our experiments indicate that converted $\mathrm{C}^{\prime} 3$ is cleared at 510 times the rate of the parent molecule, conversion induced either by constant minimal antigen-antibody interactions or by the same process of "aging," as has been observed in vitro, would necessarily produce a rapid catabolic rate.

Postulated mechanisms for the lowered complement activity observed in patients with acute glomerulonephritis, systemic lupus erythematosus, and other diseases have been summarized by Mayer (34) and include (a) complement fixation by antigen-antibody complexes or aggregated gamma globulin; $(b)$ decreased formation of one or more of the complement components; $(c)$ increased breakdown or loss; and $(d)$ formation of an inhibitor. Since in the present studies we are concerned with explaining the lowered levels of a single complement component in certain patients, and since we have used the trace-labeled component rather than its biological activity to elucidate its metabolism, the postulates can be restated as follows. The lowered concentration of $\mathrm{C}^{\prime} 3$ may be the result of $(a)$ fixation to tissues; $(b)$ decreased synthesis; and $(c)$ increased breakdown or loss.

In the patients studied, evidence was obtained that in those patients with low $\mathrm{C}^{\prime} 3$ concentrations the lowering could be explained by decreased synthesis, increased catabolism, or both. Decreased synthesis was a major factor in all of the patients with progressive glomerulonephritis and in at least one of three patients with acute glomerulonephritis. Increased catabolism was clearly evident in two of three patients with acute glomerulonephritis, all of whom had low serum $\mathrm{C}^{\prime} 3$ concentrations, and in one patient with systemic lupus erythematosus. The latter with this disease had the lowest $\mathrm{C}^{\prime} 3$ concentration and was the only untreated patient in the group of four.

Although complement activation and in vivo conversion of $\mathrm{C}^{\prime} 3$ to $\mathrm{C}^{\prime} 3_{\mathrm{i}}$ would be expected to result in elevation of the catabolic rate of injected $\mathrm{C}^{\prime} 3$, because the catabolic rate of $\mathrm{C}^{\prime} 3_{\mathrm{i}}$ is much higher than that of $C^{\prime} 3$, the finding of an elevated 
catabolic rate does not necessarily mean that complement activation in vivo has occurred. In severely affected patients with the usual type of idiopathic nephrotic syndrome of childhood, it is known that the catabolic and synthesis rates of many plasma proteins including IgG, transferrin, and albumin are often elevated (35). Many of the patients with renal disease in this study were nephrotic to a greater or lesser extent as seen in Table I. Therefore, the low synthesis rates observed in the patients with progressive glomerulonephritis are particularly striking, since all of these patients were nephrotic.

By immunofluorescent techniques, many workers have demonstrated either $C^{\prime} 3$ or $C^{\prime} 3_{i}$, or both on the glomeruli of kidney sections obtained from patients with systemic lupus erythematosus, acute glomerulonephritis, and progressive glomerulonephritis $(36,5)$. Such findings have been interpreted as evidence for in vivo complement activation in these patients. Similar observations and interpretations have been made from findings in experimental nephritis in rabbits (37). It is known that the major part $(90-95 \%)$ of $C^{\prime} 3$ in whole serum is converted to $\mathrm{C}^{\prime} 3_{\mathrm{i}}$ during in vitro complement activation (21) and only $5-10 \%$ attaches to the antigen-antibody complex or to red blood cells. It has been postulated that there is a transient, activated form of $\mathrm{C}^{\prime} 3, \mathrm{C}^{\prime} 3_{\mathrm{a}}$ that is capable of attaching to cell membranes at sites other than the antigen-antibody locus (21). Electron microscopic evidence utilizing ferritin-labeled antiserum to $C^{\prime} 3$ supports this postulate (2). Other in vitro experiments with purified $C^{\prime} 1$ esterase, $C^{\prime} 2$, and $C^{\prime} 4$ (38) demonstrated some uptake of $\mathrm{C}^{\prime} 3$ by erythrocytes without antibody or other complement components on the erythrocytes' surface. It would therefore appear most likely that during complement activation in vivo, most of the $C^{\prime} 3$ involved converts to $C^{\prime} 3_{i}$ in the plasma and only a small proportion of the molecules is actually fixed to tissues. Such tissue attachment might occur at sites more or less remote from the location of antigen-antibody complexes. If the in vitro model applies to events in vivo, attachment of $\mathrm{C}^{\prime} 3$ to tissues must represent only a minor factor in the reduction of the $C^{\prime} 3$ concentration in such a situation. A consequence of such tissue fixation might be an increase in the apparent extravascular pool of $C^{\prime} 3$. This increase was clearly found in the patient with acute glomerulonephritis with the highest catabolic rate and was possibly true of a second patient with this disease who had only a moderately increased catabolic rate. The extravascular: plasma pool ratio was elevated in only one of four patients with system lupus erythematosus, but this patient had the highest catabolic rate of the group. Definite increase in the ratio was found in one of two patients with idiopathic nephrotic syndrome and the ratio for $C^{\prime} 3_{i}$ was clearly greater than that for $\mathrm{C}^{\prime} 3$ in normal subjects. In the four studies of patients with progressive glomerulonephritis, including two studies performed with the aid of a total body counter, the extravascular: plasma ratios were entirely normal.

Urinary loss of protein-bound radioactivity was negligible in all studies, amounting to less that $5 \%$ of the total label excreted and less than $3-4 \%$ of the amount given. This confirms the finding that loss of classical third complement component by way of the urine in patients with glomerulonephritis fails to explain their low serum concentrations (39).

The metabolism of $C^{\prime} 3$ was not significantly different from that of normal subjects in patients with acquired hemolytic anemia, hereditary angioneurotic edema, rheumatoid arthritis, or paroxysmal nocturnal hemoglobinuria. Serum concentrations in these patients were in general not different from normal, so that such results are not surprising. Because of the small number of patients in each group, abnormalities of metabolism have not been excluded in all patients with these conditions but our results indicate that such abnormalities are not the rule. The failure to find increased catabolism in patients with paroxysmal nocturnal hemoglobinuria is in accord with the concept that the abnormality of the erythrocytes in patients with this disorder makes them unusually susceptible to lysis by whatever complement activation that normally occurs (25).

It should be stressed that our data show that abnormalities of metabolism can occur despite a normal serum concentration of $\mathrm{C}^{\prime} 3$ (patient M.J.K.) and that a low serum concentration may be associated with no abnormalities of metabolism, but rather with an expanded plasma volume (patient S.P.), 
As pointed out, the present metabolic studies indicate that while complement activation in vivo can be expected to produce an increase in the fractional catabolic rate (because of the rapid clearance of the conversion products of $\mathrm{C}^{\prime} 3$ generated by such activation), high fractional catabolic rates of $\mathrm{C}^{\prime} 3$ do not necessarily indicate in vivo complement activation. For this reason, other evidence for in vivo complement activation was sought. Morse, Müller-Eberhard, and Kunkel (40) have demonstrated material with the mobility of $\mathrm{C}^{\prime} 3_{\mathrm{i}}$ in the fresh EDTA plasma of one of nine patients with systemic lupus erythematosus by using immunoelectrophoresis. Our failure to detect such material, even with a more sensitive technique, may be related to the smaller number of patients that we examined, or perhaps to the fact that most of our patients were on treatment at the time of study. The plasma concentrations of $\mathrm{C}^{\prime} 3$ in our patients with systemic lupus erythematosus were in general not very low compared, for example, with some values reported by Lundh (7). This, too, speaks for milder disease at the time of study since the latter author has shown that the $C^{\prime} 3$ concentration often rises with successful steroid therapy.

Our findings in plasma from patients with acute, progressive, and subacute glomerulonephritis are difficult to reconcile with those of Soothill (41) who noted irregularities of the $\mathrm{C}^{\prime} 3$ arc in immunoelectrophoresis, irrespective of the $\mathrm{C}^{\prime} 3$ concentration in some patients with these diseases. Such irregularities may not reflect in vivo complement activation.

West, Winter, Forristal, McConville, and Davis examined $\mathrm{C}^{\prime} 3$ by immunoelectrophoresis in patients with acute and progressive glomerulonephritis (42). They found alpha 2 globulin (43), a late aging conversion product of $\mathrm{C}^{\prime} 3$, in fresh plasma from some of these patients, particularly in those in whom the level of total $C^{\prime} 3$ was low. They failed to detect material with the mobility of $\mathrm{C}^{\prime} 3_{i}$ in any specimen. Our antisera to $\mathrm{C}^{\prime} 3$ gave an excellent reaction with the $\mathrm{alpha}_{2}$ product of aging of $\mathrm{C}^{\prime} 3$, although there was no spur formation with beta $_{1 \mathrm{~A}}$ globulin in the same sample. Nevertheless, the discrepancy between our results and theirs may be due to differences in antisera.

Although small amounts of $\mathrm{C}^{\prime} 3_{\mathrm{i}}$ or beta $\mathrm{b}_{1 \mathrm{~A}}$ glob- ulin were detected in 2 of 14 normal plasma samples by antigen-antibody crossed electrophoresis, such material represented only 3 or $4 \%$ of the total C'3-related protein. Laurell and Lundh (31) have reported this phenomenon and found the presence of apparent conversion products in fresh serum or plasma an inconstant finding, even within the same sample examined on several different occasions. The detection of $\mathrm{C}^{\prime} 3_{\mathrm{i}}$ or $\mathrm{C}^{\prime} 3$-related material with the electrophoretic mobility of $\mathrm{C}^{\prime} 3_{i}$ only in patients with acute glomerulonephritis with very low concentrations of total $\mathrm{C}^{\prime} 3$, and the high percentage of this conversion product in plasma from these patients suggest that in vivo complement activation occurs in this disorder and is a probable cause of the increased catabolic rates we have observed. The absence of detectable $\mathrm{C}^{\prime} 3_{\mathrm{i}}$ does not rule out active complement fixation because of the very high fractional catabolic rate of this material. One would expect that $C^{\prime} 3_{i}$ might accumulate and be detectable only very early in the course of the disease, shortly after the onset of symptoms when the $\mathrm{C}^{\prime} 3$ concentration is falling rapidly. It is perhaps of importance that only plasma samples obtained within the first $48 \mathrm{hr}$ after the onset of symptoms of acute glomerulonephritis showed evidence of conversion products.

The failure to detect conversion products in the plasma of patients with progressive glomerulonephritis is consistent with our metabolic finding of depressed synthesis as the major cause of lowered $\mathrm{C}^{\prime} 3$ concentration in these patients. It may also be that depressed synthesis represents a later phase in acute glomerulonephritis. The lowered total serum hemolytic complement activity from patients with either of these disorders can be restored toward normal by the addition of $\mathrm{C}^{\prime} 3$ alone (20). Although $\mathrm{C}^{\prime} 3$ concentration does not return to normal for 4-6 wk (3) after the onset of clinical acute glomerulonephritis, $\mathrm{C}^{\prime} 4$ returns to normal considerably earlier (44). These observations tend to support our findings of depressed synthesis.

The mechanism for lowered synthesis is obscure, but it may well represent a protective negative feedback that tends to prevent further self-damage from continuing complement activation. A speculative mechanism for the lowered synthesis might be derived from the observation (45) that macro- 
phages may be the site of synthesis of $\mathrm{C}^{\prime} 3$. If this is so, and since the concentration of $\mathrm{C}^{\prime} 3$ is perforce highest at the site of synthesis, macrophages producing the protein might be injured or destroyed during in vivo complement fixation.

\section{Acknowledgments}

We are grateful to Drs. F. X. Fellers, F. H. Gardner, L. K. Diamond, S. S. Gellis, and D. Whitten for giving us the opportunity to study their patients and to Dr. C. A. Janeway for helpful advice and invaluable criticism. We thank Mr. L. Button for performing estimations of plasma volumes with radioiodine-labeled albumin. We thank Drs. S. Ingbar, K. Woeber, and E. Socolow and Mrs. M. Halloway for carrying out the radioautography in the earlier parts of this study. We are indebted to Dr. J. Katz and B. Burrows for help with and permission to use the total body isotope counter at The Evans Memorial Department of Research, Boston University Medical Center. Parke, Davis and Company kindly donated the chloramphenicol used during the preparation of $\mathrm{C}^{\prime} 3$ for some of the studies. We also wish to thank Drs. M. Klemperer and V. Donaldson for their help with complement assays, and Dr. J. H. Peters for doing Kjeldahl analyses.

\section{References}

1. Müller-Eberhard, H. J., U. R. Nilsson, A. P. Dalmasso, M. J. Polley, and M. A. Calcott. 1966. A molecular concept of immune cytolysis. Arch. Pathol. 82: 205.

2. Nelson, Robert A., Jr. 1965. The role of complement in immune phenomena. In The Inflammatory Process. B. W. Zweifach, L. Grant, and R. T. McCluskey, editors. Academic Press Inc., New York. 819.

3. West, C. D., J. D. Northway, and N. C. Davis. 1964. Serum levels of $\beta_{1 \mathrm{c}}$-globulin, a complement component, in the nephritides, lipoid nephrosis, and other conditions. J. Clin. Invest. 43: 1507.

4. Klemperer, M. R., S. P. Gotoff, C. A. Alper, A. S. Levin, and F. S. Rosen. 1965. Estimation of the serum beta $a_{1 c}$ globulin concentration: its relation to the serum hemolytic complement titer. Pediatrics. $35: 765$.

5. Gotoff, S. P., F. X. Fellers, G. F. Vawter, C. A. Janeway, and F. S. Rosen. 1965. The beta 1 globulin in childhood nephrotic syndrome: laboratory diagnosis of progressive glomerulonephritis. New Engl. J. Med. 273 : 524.

6. Seligmann, M., and C. Hanau. 1958. Etude immunoélectrophorétique du sérum de malades atteints de lupus érythémateux disséminé. Rev. Hematol. (Paris) $13: 239$.

7. Lundh, B. 1965. $\beta_{1 \mathrm{c}}$-globulin and trypsin inhibitors in systemic lupus erythematosus and rheumatoid arthritis. Acta Universitatis Lundensis, Section II. 25 .
8. Laurell, C.-B. 1965. Antigen-antibody crossed electrophoresis. Anal. Biochem. 10:358.

9. Alper, C. A., A. S. Levin, and F. S. Rosen. 1966. Beta-1c-globulin: metabolism in glomerulonephritis. Science. $153: 180$.

10. Müller-Eberhard, H. J., U. Nilsson, and T. Aronsson. 1960. Isolation and characterization of two $\beta_{1}$-glycoproteins of human serum. J. Exptl. Med. $111: 201$.

11. Nilsson, U. R., and H. J. Müller-Eberhard. 1965. Isolation of $\beta_{1}$-globulin from human serum and its characterization as the fifth component of complement. J. Exptl. Med. 122 : 277.

12. McFarlane, A. S. 1958. Efficient trace-labelling of protein with iodine. Nature. $182: 53$.

13. Reif, A. E. 1966. A simple procedure for high efficiency radioiodination of antibodies. Federation Proc. 25: 726. (Abstr.)

14. Laurell, C. B., S. Laurell, and N. Skoog. 1956. Buffer composition in paper electrophoresis. Considerations on its influence, with special reference to the interaction between small ions and proteins. Clin. Chem. 2: 99.

15. Scheidegger, J. J. 1955. Une micro-méthode de l'immunoélectrophorèse. Intern. Arch. Allergy Appl. Immunol. 7: 103.

16. Müller-Eberhard, H. J., and U. Nilsson. 1960. Relation of a $\beta_{1}$-glycoprotein of human serum to the complement system. J. Exptl. Med. 111: 217.

17. Lundh, B. 1965. The effect of incubation with hydrazine and immunoprecipitate on $\beta_{1 \mathrm{e}}$-globulin. Acta Pathol. Microbiol. Scand. 63: 266.

18. Poulik, M. D. 1957. Starch gel electrophoresis in a discontinuous system of buffers. Nature. 180: 1477.

19. Laurell, C.-B., and J.-E. Niléhn. 1966. A new type of inherited serum albumin anomaly. J. Clin. Invest. $45: 1935$.

20. Klemperer, M. R., S. P. Gotoff, C. A. Alper, and F. S. Rosen. 1966. Beta-1c-globulin in glomerular nephritis. Pediatrics. 37: 529 .

21. Müller-Eberhard, H. J., A. P. Dalmasso, and M. A. Calcott. 1966. The reaction mechanism of $\beta_{10}-$ globulin $\left(C^{\prime} 3\right)$ in immune hemolysis. J. Exptl. Med. 123: 33.

22. Kabat, E. A., and M. M. Mayer. 1961. Experimental Immunochemistry. Charles C Thomas, Springfield. 2nd edition. 152.

23. Feinberg, J. G. 1959. A specific assay method for biologic solutions with particular reference to allergen extracts. Immunology. 2: 346.

24. Laurell, C.-B. 1966. Quantitative estimation of proteins by electrophoresis in agarose gel containing antibodies. Anal. Biochem. 15: 45.

25. Yachnin, S. 1965. The hemolysis of red cells from patients with paroxysmal nocturnal hemoglobinuria by partially purified subcomponents of the third complement component. J. Clin. Inz'est. 44: 1534.

26. Lowry, O. H., N. J. Rosebrough, A. L. Farr, and 
R. J. Randall. 1951. Protein measurement with the Folin phenol reagent. J. Biol. Chem. 193: 265.

27. Kabat, E. A., and M. M. Mayer. 1961. Experimental Immunochemistry. Charles C Thomas, Springfield. 2nd edition. 480.

28. Matthews, C. M. E. 1957. The theory of tracer experiments with ${ }^{181} \mathrm{I}$-labelled plasma proteins. Phys. Med. Biol. 2 : 36 .

29. Campbell, R. M., D. P. Cuthbertson, C. M. Matthews, and A. S. McFarlane. 1956. Behaviour of ${ }^{14} \mathrm{C}-$ and ${ }^{181} \mathrm{I}$-labelled plasma proteins in the rat. Intern. J. Appl. Radiation Isotopes. 1: 66 .

30. Alper, C. A., T. Freeman, and J. Waldenström. 1963. The metabolism of gamma globulins in myeloma and allied conditions. J. Clin. Invest. $42: 1858$.

31. Laurell, C.-B., and B. Lundh. 1967. Electrophoretic studies of the conversion products of serum $\beta_{1 \mathrm{c}}$-globulin. Immunology. 12: 313 .

32. McFarlane, A. S. 1964. Metabolism of plasma proteins. In Mammalian Protein Metabolism. H. N. Munro and J. B. Allison, editors. Academic Press Inc., New York. 1: 322.

33. Freeman, T. 1964. Haptoglobin metabolism in relation to red cell destruction. In Protides of the Biological Fluids. Proceedings of the Twelfth Colloquium. H. Peeters, editor. Elsevier Publishing Co., Amsterdam. 344.

34. Kabat, E. A., and M. M. Mayer. 1961. Experimental Immunochemistry. Charles C Thomas, Springfield. 2nd edition. 234.

35. Gitlin, D., C. A. Janeway, and L. E. Farr. 1956. Studies of the metabolism of plasma proteins in the nephrotic syndrome. I. Albumin, $\gamma$-globulin and iron-binding globulin. J. Clin. Invest. $35: 44$.

36. Lachmann, P. J., H. J. Müller-Eberhard, H. G. Kunkel, and F. Paronetto. 1962. The localization of in vivo bound complement in tissue sections. J. Exptl. Med. 115 : 63.

37. Unanue, E., and F. J. Dixon. 1964. Experimental glomerulonephritis. IV. Participation of complement in nephrotoxic nephritis. J. Exptl. Med.119: 965.

38. Müller-Eberhard, H. J., M. J. Polley, and M. A. Calcott. 1967. Formation and functional significance of a molecular complex derived from the second and fourth component of human complement. J. Exptl. Med. $125: 359$.

39. Lange, K., and E. J. Wenk. 1954. Complement components in the sera and urines of patients with severe proteinurias. Am. J. Med. Sci. 228: 448.

40. Morse, J. H., H. J. Müller-Eberhard, and H. G. Kunkel. 1962. Antinuclear factors and serum complement in systemic lupus erythematosus. Bull. N. Y. Acad. Med. 38 : 641.

41. Soothill, J. F. 1967. Altered complement component $\mathrm{C}^{\prime} 3 \mathrm{~A}\left(\boldsymbol{\beta}_{1 \mathrm{C}}-\boldsymbol{\beta}_{\mathbf{1 A}}\right)$ in patients with glomerulonephritis. Clin. Exptl. Immunol. 2 : 83.

42. West, C. D., S. Winter, J. Forristai, J. M. McConville, and N. C. Davis. 1967. Evidence for in vivo breakdown of $\beta_{1 \mathrm{c}}$-globulin in hypocomplementemic glomerulonephritis. J. Clin. Invest. 46 : 539 .

43. West, C. D., N. C. Davis, J. Forristal, J. Herbst, and R. Spitzer. 1966. Antigenic determinants of human $\beta_{1 \mathrm{C}^{-}}$and $\beta_{1 \mathrm{G}}$-globulins. J. Immunol. 96: 650 .

44. Kohler, P. F., and H. J. Müller-Eberhard. 1967. Complement component quantitation: Immunoassay of $C^{\prime} 3, C^{\prime} 4$, and $C^{\prime} 5$. Clin. Res. 15: 296.

45. Stecher, V. J., E. B. Jacobson, and G. J. Thorbecke. 1966. Formation of $\beta_{1 \mathrm{c}}$ by peritoneal macrophages. Federation Proc. 24 : 447. (Abstr.) 